\title{
Technological Aspects of Formation of Energy-efficient Photovoltaic Solar Energy Converters
}

\author{
O.Y. Nebesniuk* Z.A. Nikonova, A.A. Nikonova \\ Engineering Educational and Scientific Institute of Zaporizhzhia National University, \\ Soborniy Ave., 226, 69006 Zaporizhzhia, Ukraine
}

(Received 25 July 2021; revised manuscript received 20 October 2021; published online 25 October 2021)

\begin{abstract}
Nowadays there is an increasing demand for alternative energy sources used in the national economy, industry and everyday life. Solar energy is one of the most promising alternatives to traditional methods of electricity generation. The actual problem is the development of economic and renewable technologies in the production of photovoltaic converters (PVC) based on poly- and monocrystalline silicon. The trends in the creation of the most complex electronic devices based on multilayer epitaxial structures are clearly manifested. At the same time, very high requirements are imposed on the electrophysical properties and perfection of the structure of each layer, the problems of creating perfect and sharp $p$ - $n$ junctions and heteroboundaries on large areas of epitaxial compositions are posed. The article proposes new technological aspects of the formation of silicon nanostructures with transparent coatings, which will significantly improve the quality of $\mathrm{PVC}$ on their basis with an efficiency of up to $27 \%$ that will give impetus to the formation of new energy systems.
\end{abstract}

Keywords: Solar energy, Technology, Structure, Photovoltaic converters, Silicon, Nanostructures, Transparent luminous spheres, Options, Energy efficiency, Characteristics.

DOI: 10.21272/jnep.13(5).05033

PACS numbers: 85.40.Ls, 85.40.Ry

\section{INTRODUCTION}

With climate change, low-carbohydrate raw materials, financial and energy crises, interest in renewable energy sources has grown. Solar power plants are a perspective direction of energy development in the 21 st century. The desire to get rid of energy dependence in the European Community has led to the greatest investment project (DESERTEC) worth $\$ 555$ billion. The project includes the construction of 100 large solar power plants in the Sahara Desert. If this is really implemented, the generated energy will be enough for $15-25 \%$ of the needs of both Europe and all countries of South Africa.

It is known that a consortium of the greatest companies and European banks to finance the construction was created on the basis of a parabolic concentrator of solar radiation to heat the coolant (oil) to parameters suitable for use in a turbogenerator (thermoeffect).

According to the Global Market Outlook 2016-2020, the fall in solar energy prices around the world is still continuing.

According to the annual tender in Dubai at the beginning of 2015 , the price of $\$ 58.4$ per MWh per year was fixed. As a result, the tender organizer, Dubai Energy and Water Authority (DEWA), increased twice up to $200 \mathrm{MWh}$ the primary size of the project. Recently, as a result of the tender, cases of even lower prices have been registered, including without state financial support. In 2016 in Paris, the price was $\$ 36$ per MWh per year. The peak price of the annual tender was $800 \mathrm{MWh}$ in UAE, which is $\$ 29.9$ per MWh per year, while competitive proposals were suggested with very low quotes of \$36.5-45 per MWh per year. A good demonstration of fast solar energy is the case of a consortium of investors, who won the tender mentioned above at $\$ 58.4$ per MWh per year. Less than a half a year, they won a new tender in Dubai at $\$ 39.5$ per MWh per year, which is lower by $30 \%$.

The minimum price for solar energy converters is $\$ 0.37 / \mathrm{Wh}$ (China), \$0.29/Wh (Canadian Solar company). Meanwhile, a minimum import rate is set at the European market, at which the price of foreign PVC supplied to Europe cannot be lower than 56 euros per Wh that gives corresponding preferences to European manufacturers.

Last year, the capacity of solar power plants in the EU exceeded $100 \mathrm{GW}$. It is predicted that by 2025 it will be increased to a minimum of $129.6 \mathrm{GWh}$ (pessimistic outlook) or a maximum of $170.9 \mathrm{GWh}$ (optimistic outlook). According to the results of 2020, Europe remains the "sunniest continent" in terms of fixed capacity, but this year it is likely to be ahead of Asia.

By the end of 2021, the capacity of solar power plants in the world will reach $600 \mathrm{GWh}(229 \mathrm{GWh}$ in 2019), and with an optimistic outlook it, could reach $700 \mathrm{GWh}$. In the EU, according to the fixed capacity (in descending order): the leaders are Germany, Italy, Great Britain, France, Spain. Today solar energy produces $4 \%$ of the electricity in the EU. In Italy, Greece and Germany its share exceeds $7 \%$.

By a pessimistic outlook of development, solar energy will provide $10 \%$ of European electricity by 2030 .

The source of solar radiation energy is a thermonuclear reaction [1]. Every second on the Sun, $61011 \mathrm{~kg}$ of hydrogen is converted into helium. The mass excess is $4000 \mathrm{~kg}$, that is, according to the Einstein ratio $E=m c^{2}$, this leads to $4120 \mathrm{~J}$ energy liberation. The main part of this energy is consumed with electromagnetic radiation in the range $0.2-3 \mu \mathrm{m}$. Since the total mass of the Sun is $\sim 21030 \mathrm{~kg}$, it can be in a stable state for more than 10 billion years with constant energy release. Thus, using highly effective methods of

*0811oksana@gmail.com 
converting energy, the Sun can constantly meet the growing needs for it.

Solar energy [2] is not only inexhaustible and free, but it is also the most environmentally friendly among other available energy sources. Every $8 \mathrm{~min}$, energy comes from the Sun in the amount that people spend for the whole year. The entire human need for energy can be provided by solar energy that reaches the Earth in just one day, 180 years ahead. In its pure form, the Sun sends $960,000,000,000 \mathrm{kWh}$ of energy to our planet every day. This means that humanity cannot neglect such a source of energy. The amount of solar energy per year per unit area is $1000-1350 \mathrm{kWh} /$ year $/ \mathrm{m}^{2}$. According to the solar radiation intensity, our country can be divided into 4 regions: Western, Central, South-Eastern and Southern. The average solar radiation intensity here is $1200 \mathrm{kWh} /$ year $/ \mathrm{m}^{2}$.

The authors consider the following disadvantages of using solar energy:

- high cost of solar energy converters;

- electricity production only during daylight hours;

- dependence on climatic conditions;

- the need for large areas for the construction of solar power plants;

- problems with energy storage;

- imperfection of technology and low coefficient of performance.

The development of solar energy and the need for energy conservation around the world are the most urgent environmental problems. This requires some conditions:

- the presence of long daylight hours;

- prevalence of clear sunny weather in the daytime;

- a large angle of incidence of sun rays, which is measured by the latitude of the geographical area: the closer to the equator, the greater the angle of incidence of sun rays.

According to natural factors, the most favorable regions for the development of solar energy are countries of tropical and subtropical climatic zones, where there are high indexes of daylight hours and insolation for the whole year. In temperate latitudes, the most preferable conditions are seen in the summer season, and cloudiness in the middle of daylight is a negative factor in the equator zone [3].

Today, there are 3 main areas of sun energy use:

- solar water heating installations (collectors);

- solar power plants (SPP);

- photoelectric converters (PECs).

It took half a century for the first solar photocells to appear with an efficiency of no more than $1 \%$, though more efficiency was required for photoelectric energy.

A critical moment for this direction was the creation of silicon solar cells with a $p-n$ junction, which had a performance of about $6 \%$. And, as it is known, the first practical use of silicon solar cells for energy purpose took place not on Earth, but in space [4-6].

It can be noted that the scientific basis for the creation of the first solar cells was the development of technologies for semiconductor materials and structures. The main areas of application of devices based on semiconductor materials at that time were observed in energy conversion technology (AC-to-DC conversion, highfrequency generator, etc.) and in the transmission and processing of electronic information (radio, telecommunication, etc.). In addition to the "classical" semiconductor materials - germanium and silicon, since 1950 [7], the synthesis of materials of the $\mathrm{A}^{\mathrm{III}} \mathrm{B}^{\mathrm{V}}$ type has begun.

It has been established that in modern solar energy systems, more than $85 \%$ of PEC are made on the basis of crystalline silicon slabs, their cost is more than $50 \%$ of the total PEC cost. Therefore, it is very important to develop and master new technological aspects of creating energy-efficient PEC based on crystalline silicon with high performance characteristics.

One of the most general directions of direct solar energy conversion into electrical one is realized in semiconductor PECs. Until now, the most commercial solar cell modules are based on crystalline Si with an efficiency $\eta \leq 20 \%$ (first generation PEC) and amorphous thinfilm solar cells with a large area of PEC with $\eta \sim 5-8 \%$ (second generation PEC). The third-generation concept is the use of nano- and microstructures (microwires). PEC with microwires (Vapor-Liquid-Solid (VLS) method)) refers to devices with a unique design for obtaining directional carrier transport, taking into account the geometry of such structures [8].

For the effective work of PECs, certain conditions are necessary:

- the optical absorption index of the semiconductor active sphere must be large enough to ensure the absorption of most of the sunlight within the sphere thickness;

- electrons and holes generated in the light must be efficiently collected on the contact electrodes from both sides of the active sphere;

- PEC must have a large barrier height in the semiconductor junction.

- the total resistance connected in series with the solar cell (excluding load resistance) must be low to reduce power losses (joule heat) in the working process;

- the thin-film structure must be uniform over the entire area of the active solar cell in order to exclude circuit failure and influence on its parameters and characteristics.

Today, PECs based on mono- and polycrystalline silicon and multicomponent compounds CdTe, $\mathrm{CuInSe}_{2}$ (CIS) and $\mathrm{Cu}(\mathrm{In}, \mathrm{Ga}) \mathrm{Se}_{2}$ (CIGS) are widespread on the market. The efficiency of such panels is 10-26\%. Although PECs with monocrystalline (c-Si) and polycrystalline (poly-Si) silicon are widely proposed on the market, batteries based on monocrystalline silicon, as usual, have an efficiency within 20-26\% and based on polycrystalline silicon - 12 $21 \%$ although they are cheaper. Since the cost of the watt power (on the basis of produced power) is almost the same for the finished panels, batteries with monocrystalline silicon are even advantageous. According to such parameters as degradation quality and speed, there is no difference between them. Therefore, the choice of monocrystalline silicon is evident. Besides, in low light conditions, monocrystalline silicon provides the nominal power longer than polycrystalline one, and this allows to get some energy even in very inclement weather and at dusk. It is necessary to pay special attention to the electrical characteristics of the panels (nominal and maximum voltage) when choosing solar panels. In the domain of converting solar 
photovoltaic energy into electrical, the focus is on how PECs work with nanostructures made of monocrystalline silicon.

It is proved that about $91 \%$ of incident light energy can be converted into electric current in a silicon PEC if to solve problems of discharge of charge carriers from the semiconductor volume. The low price of silicon is the main factor when choosing a material for them. According to the International Energy Agency, the total capacity of solar photoelectric installations in the world will reach $900 \mathrm{GWh}$ by 2030, $2000 \mathrm{GWh}$ by 2040, $3000 \mathrm{GWh}$ by 2050 , which will be $25 \%$ of the world's electricity on the planet. As known, the most developed market for photovoltaic energy is the segment of municipal housing, its planned volume is 10 million. As for solar roofs, the average roof energy capacity is $3 \mathrm{kWh}$ and the average world price of such a roof is $\$ 17000$, which means that the global market capacity in this segment is $\$ 170$ billion. It is an established segment of the global photovoltaic energy market that is rapidly developing with tremendous growth. At the moment, solar roofs are generally created on the basis of silicon solar PECs. The main customers are city and country dwellers in the developed countries and in countries with high insolation level [9-12].

In Ukraine, the PEC market in the segment of municipal housing does not exist in connection with the absence of a state program for the development of photovoltaic energy and a legal framework that stimulates the development of this segment. Although the prospect of its development for Ukraine is evident due to the constant rise in electricity prices and geographic location, where $3 / 4$ of the population ( 30 million people) live in regions with high solar radiation level. It is expected that over the next 20 years, solar photovoltaic energetics will create more than 2 million working places, reduce greenhouse gas emissions into the atmosphere by 350 million tons of $\mathrm{CO}_{2}$, that is equivalent of shutting down 150 coal-fired power plants.

The aim of this work is to investigate and develop an economically profitable technology for the production of efficient solar power PECs.

\section{DESCRIPTION OF THE OBJECT AND METHODS OF RESEARCH}

The authors believe that the main factor in choosing the direction, in which the development and improvement of technologies for obtaining silicon PECs must be done, is the use of already existing technologies. For the practical use of solar energy, first of all, it is necessary to reduce the cost of PECs with savings in efficiency. This problem is associated with the volume of output, which should double in comparison with the present one, therefore, such a decrease in the cost of production can be achieved by miniaturizing their designs, placing a large number of scheme elements on one slab, using high-quality nanostructures and new technological aspects of PEC formation, proposed by the authors, that will increase their effectiveness.

One of these technological aspects of PEC creation was based on the preparation of the starting material, the production and cutting of special monocrystalline silicon ingots. Since during crystal growth there was a fairly large scatter (up to $30 \%$ ) of the resistivity, this made it possible to use almost the entire dislocationfree part of the ingot. In connection with the rise of demands for photoelements (the spread of characteristics is allowed up to $5 \%$ ), the useful length of the ingot was successfully reduced by $1 / 3$. During the experiment, silicon oxide from the surface of silicon patterns was removed with etching, that consisted of equal parts of hydrofluoric acid and deionized water.

The next technological aspect of the PEC formation was the creation of the structure of ITO $/ n-\mathrm{Si} / n^{+}$-Si type. It was made on the basis of monocrystalline silicon slabs grown in the [111] direction, which had a resistivity of $0.01 \mathrm{Ohm} \mathrm{cm}$, a diameter of $7.6 \mathrm{~mm}$, a thickness of $3.8 \cdot 10^{2} \mathrm{~nm}$ with an epi-layer on the working surface. For this purpose, monocrystalline and silicon ingots of a cylindrical shape were calibrated to a diameter of $76 \pm 0.2 \mathrm{~mm}$, then a basic cut was made for the orientation of the plates in subsequent operations and marking. The slabs were prepared by cutting silicon ingots with diamond wheels ABPK. The orientation accuracy of cutting direction was $\pm 0.2^{\circ}$. The slabs were washed and etched in a concentrated solution at $75-90^{\circ} \mathrm{C}$ for $60-90 \mathrm{~s}$. Then, the slabs were sorted by geometric size and polished first with diamond paste ACM 2/1, and then with an aluminosilicate suspension, that had a size of abrasive particles of less than $0.3 \mu \mathrm{m}$. This operation guaranteed the absence of a broken sphere on the slab. After washing the slabs with hydrogenous chlorosilane restoration method, an epi-layer was formed. It had the following parameters: $n^{+}$-type conductivity, resistivity from 0.5 to $40 \mathrm{Ohm} \mathrm{cm}$, thickness from $1 \cdot 10^{2}$ to $1 \cdot 10^{3} \mathrm{~nm}$.

The production of epitaxial layers on silicon wafers was carried out on a special installation. It consisted of two vertical water-cooled reactors with a volume of 201 made of stainless steel, a gas distribution control panel, a thyristor convertor, a power control panel, a program device, that provided automatic conduction of the epi-layer deposition process. Silicon slabs were laid on the carbon pyramid, its edges needed grinding. The pyramid was heated by high voltage using a water-cooled inductor. This made it possible to obtain high quality nanostructures.

It is stated that one of the ways to increase the efficiency of solar cells in the of the spectrum is to cover the photosensitive surface of the PVC with a transparent luminous sphere. The use of a luminous coating allows to reduce the reflection coefficient of light from the transparent silicon surface in the $4-11 \mathrm{~nm}$ spectral range. The result is improved performance and longer service life. Among the materials that are promising for silicon PEC luminous coatings, $\mathrm{SnO}_{2}$ and $\mathrm{In}_{2} \mathrm{O}_{3}$ stand out, they are highly transparent in the assigned spectral range. Besides, such coatings protect the elements from damage caused by radiation in space and unfavorable atmospheric influences on the Earth.

During the experiment, the use of $\mathrm{In}_{2} \mathrm{O}_{3}+\mathrm{SnO}_{2}$ was proposed as luminous coatings. To produce spheres from tin oxide, indium oxide and their compounds, the authors of this article developed a technology, specially produced a research industrial installation, which consisted of a silicon slab heater and a vertical-jet quartz spray. The gas supply system included a reduction gear, a gas purification filter of dust particles, moisture and oil, as well as a flow-rate regulator. The spray solution 
was supplied periodically. The supply and the pause time of the solution supply were regulated by an electronic unit that controlled the operation of the gas flow regulator and the isolator valve. The heater temperature was controlled using a thermocouple, its hot junction was placed into the test tube to provide safe thermal contact. To create satisfactory conditions for the spheres installation, the slabs were protected by a quartz display. The configuration of the spray nozzle and the choice of diameter provided a thin jet of solution. To obtain tin and indium oxides, the solutions of their chlorides $\mathrm{SnCl}_{4}, \mathrm{InCl}_{3}$ from 5 to $15 \%$ were used, and ethanol water was used as a solvent for chlorides. A solution of some salts was sprayed with a single spray.

The use of technology based on the spray method provided stable results. In this method, an alcohol or hydrogen solution is sprayed on the heated substrate. This solution contains components of a compound that precipitates on the surface. Fine drops of the sprayed solution create separate crystals on the surface of the substrate, because the pyrolysis process is endothermic. To compensate for heat loss, thermal energy was supplied to the lining, which was necessary for the process of agglomeration of individual crystals and the process of their recrystallization, from whence a homogeneous film of sedimentary material was created.

It was found that the conductivity nature of the ITO sphere changes depending on the composition of $\mathrm{SnO}_{2}$ for the following reasons.

At low concentration of $\mathrm{SnO}_{2}$ in $\mathrm{In}_{2} \mathrm{O}_{3}+\mathrm{SnO}_{2}$, indium atoms are replaced by a tin atom. As a result, tin acts as a donor in the crystal lattice of indium dioxide. At higher concentrations of $\mathrm{SnO}_{2}$, conditions for $\mathrm{SnO}_{2}$ complexes of neutral molecules were created. Sn atoms that have created donor levels with low concentrations create neutral complexes with high concentrations. This is the reason for the drop in conductivity. The ITO spheres had the highest conductivity, they contained about $7.7 \cdot 10^{-4} \mathrm{~g} / \mathrm{mole} \mathrm{SnO}_{2}$.

The use of proposed coatings will increase the efficiency of the device structure up to $27 \%$. Studies of the radiation spectrum showed a minimum resistance of the PEC surface of about $2.3 \%$ at a wavelength of $630 \mathrm{~nm}$ and an average resistance of $7 \%$ at a wavelength of $400-1000 \mathrm{~nm}$. Thus, as the investigation results show, the double sphere $\mathrm{In}_{2} \mathrm{O}_{3}+\mathrm{SnO}_{2}$ is characterized by a high absorption capacity and can be used to increase the PEC efficiency.

\section{DESCRIPTION AND ANALYSIS OF RESULTS}

The authors conducted research and defined technological aspects that influence the quality and efficiency of PECs. Temperature and illumination have a large impact on the PEC initial power, though the influence of these parameters is ambiguous and varies depending on the type of the PEC basic sphere. The efficiency of PECs based on silicon decreases with an increase in the temperature of the device structure. At the same time, thin-film PECs demonstrate less legal tendencies, with the additional influence of the formation technology of the device structure. An increase in the PEC temperature leads to changes in the semiconductor properties, as a result of which there is a decrease in the band gap with increasing temperature. With a decrease in the semiconductor band gap, there is a slight increase in the short-circuit voltage: it increases by $(1.5-3) \cdot 10^{-5}$ when the temperature rises by $1{ }^{\circ} \mathrm{C}$, since photons with low energy can stimulate electrons to go into the band gap. An increased PEC temperature has a significant effect on the value of the open-circuit voltage $U_{o c}$, which depends on the temperature according to the formula:

$$
\frac{U_{o c}}{T}=0.00288
$$

and corresponds to a change in electromotive force of approximately $0.5 \%$ per $1{ }^{\circ} \mathrm{C}$. Since quasi-Fermi level splitting also decreases with decreasing band gap, this leads to a drop in the open-circuit voltage of the device.

Therefore, the question of the temperature dependence of the PEC efficiency remains controversial.

An increase in the initial characteristics of silicon PECs was achieved during the experimental research, first, by increasing the open-circuit voltage $U_{o c}$, because its size also depends on the $\mathrm{SnO}_{2}$ compound in the ITO sphere applied to an $n n^{+}$silicon epi-structure, Fig. 1. The highest values of $U_{o c}(530 \mathrm{~mW})$ were achieved with the ITO compound, which contained $>95 \% \mathrm{In}_{2} \mathrm{O}_{3}$ and $3 \% \mathrm{SnO}_{2}$. During the process, the thickness of the applied sphere was defined for interference color.

It was determined that the value of $U_{o c}$ also depends on the thickness of the ITO sphere (Fig. 2) and reaches $0.5 \div 0.55 \mathrm{~V}$ on slabs deposited at a temperature of 420 $440{ }^{\circ} \mathrm{C}$ and with $1100 \AA$ sphere thickness. Under AM1 illumination, the short-circuit current was $25 \div 30 \mathrm{~mA} / \mathrm{sm}^{2}$ (Fig. 3) and the efficiency of the device structure was 20$25 \%$. Meanwhile, a double-sphere coating led to a sharp increase in the photocurrent in the device structure from 40 to $60 \%$ which is also an important parameter of PECs.

The next technological aspect was our study of the reflection index of the ITO sphere at $1000 \AA$ thickness depending on the $\mathrm{SnO}_{2}$ content in ITO (Fig. 4). For this, samples were taken without $\mathrm{SnO}_{2}$ content and with $\mathrm{SnO}_{2}$ content in ITO equal to $0.38 \cdot 10^{-4}, 7.7 \cdot 10^{-4}$, and $12 \cdot 10^{-4} \mathrm{~g} /$ mole and with a polished silicon surface.

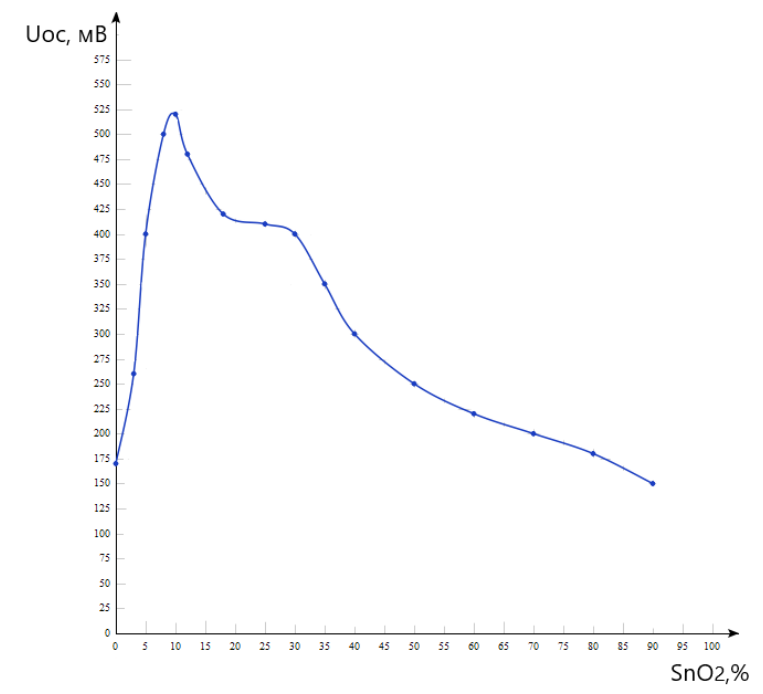

Fig. 1 - Dependence of the open-circuit voltage $U_{o c}$ of the ITO layer on the composition of $\mathrm{SnO}_{2}$ 


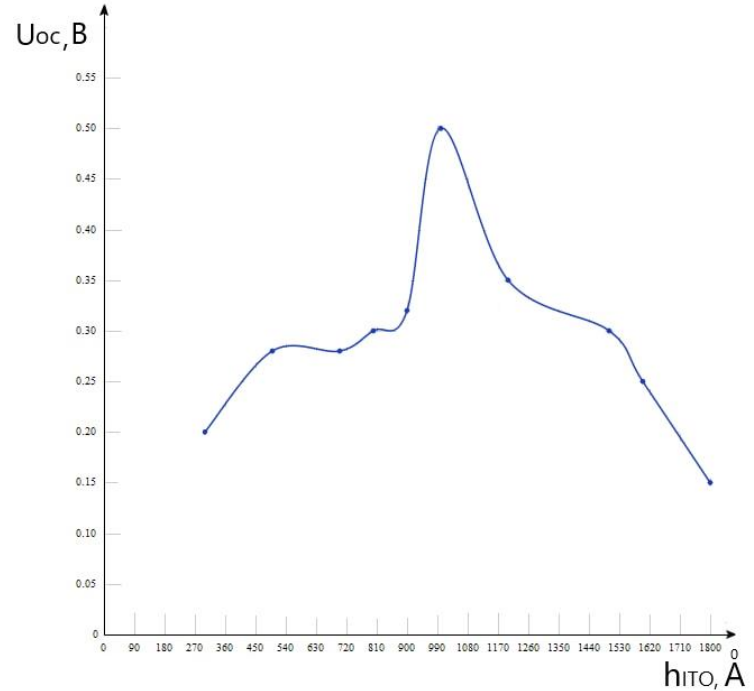

Fig. 2 - Dependence of the open circuit voltage $U_{o c}$ on the ITO layer thickness

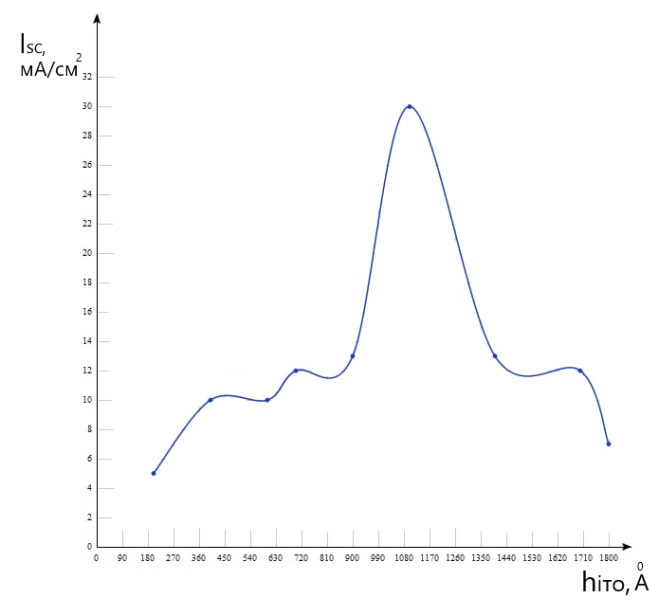

Fig. 3 - Dependence of the short-circuit current $I_{s c}$ on the ITO layer thickness

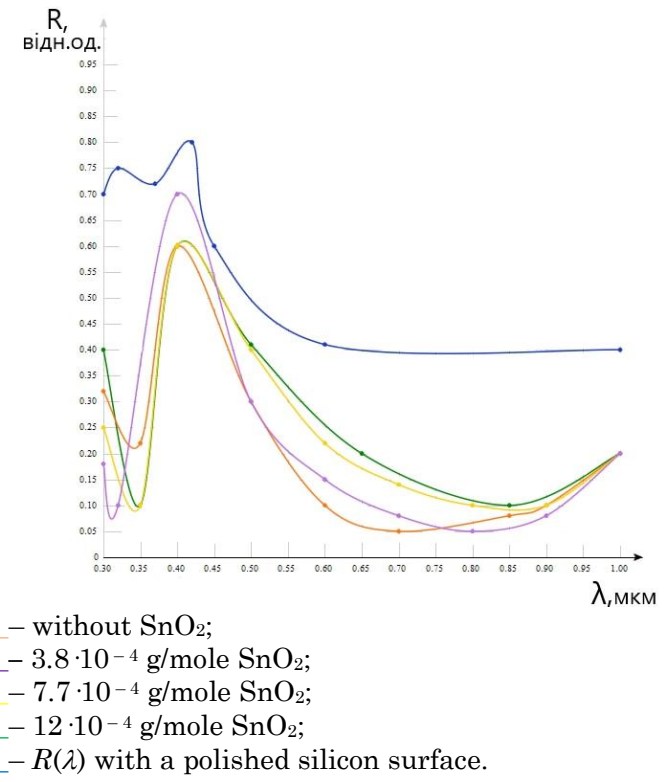

Fig. 4-Measured values of the reflection coefficient $R(\lambda)$ of the ITO layer at different composition of $\mathrm{SnO}_{2}$
The maximum reflection coefficient was obtained for photoconverters with a $\mathrm{SnO}_{2}$ content of $7.7 \cdot 10^{-4} \mathrm{~g} / \mathrm{mole}$. Under these conditions, the load characteristic of the solar cell was determined (Fig. 5), the operating efficiency was $\delta=0.62$ and the efficiency was $\eta=21.3$.

The PEC efficiency was determined on a specially created laboratory system of sorting photoconverters, and the definition procedure was as follows: the voltage generated by the PEC, which was placed on an illuminated table, was removed and then fed to the comparator block, where it was compared with a refence voltage, meanwhile, a signal was generated that was received on the relay block.

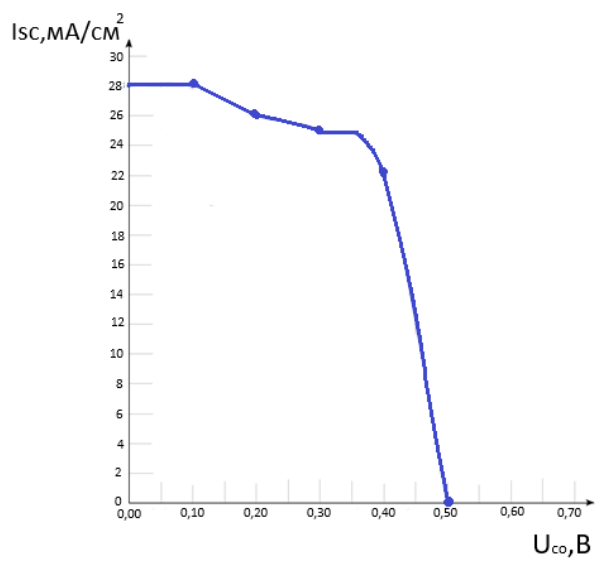

Fig. 5 - Load characteristics of the solar cell with a transparent/translucent coating (AM1 illumination)

It was adapted that the maximum power is provided by the PEC in the case, when the voltage reaches $0.4 \mathrm{~V}$. If the voltage on the PEC exceeds $0.4 \mathrm{~V}$, one or several resistors of $\mathrm{P} 1-\mathrm{P} 4$ contacts fail. If the voltage on the PEC is less than $0.4 \mathrm{~V}$, the contacts are opened, and one or more resistors are connected. The voltage taken from the resistor $R_{0}$, which serves as a current sensor, was also fed to the comparator block and compared with the reference voltage and the flowing current $\left(I \sim U / R_{0}\right)$. The fixed signal graduated in efficiency was reflected on the indication block.

An important technological aspect was also the deposition of a metal coating on the surface of silicon slabs by the metal evaporation method in a vacuum on $\mathrm{YBH}$ $71 \mathrm{P} 2$ installation. It is a system consisting of two vacuum pumps, oil-vapor and vapor-steam, connected with the pumping chamber. It had a carousel, with fixed silicon slabs, rotating in a horizontal plane. Thermal spraying of the metal was conducted in a boat made of refractory metal - tungsten and tantalum, which provided a uniform surface.

Copper with lower resistivity was used as a currentcollecting contact for silicon. Since chromium has high oxidation tenacity and good adhesion to silicon, it was used to protect copper contact from the environment influence and as a copper subsphere. Working and nonworking contacts were created by vacuum deposition method of chromium and copper spheres. The thickness of metal stripes ranged from 100 to $500 \mu \mathrm{m}$, the distance did not exceed $5 \%$. Minimizing the contact area turned out to be the most effective of the many ways to increase the recombination losses at the metal/ 
semiconductors interface. Thus, the authors have proposed constructive and technological aspects of the formation of PECs of solar energy, which will significantly affect the increase in their efficiency.

\section{CONCLUSIONS}

As a result of the proposed constructive and technological decisions, the authors managed to:

- increase the photocurrent $I_{p h}$ to $60 \%$ and the open-circuit voltage $U_{o c}$ to $530 \mathrm{mV}$ for the ITO-layer, which contains more than $95 \% \mathrm{In}_{2} \mathrm{O}_{3}$ and $3 \% \mathrm{SnO}_{2}$;

- increase the value of the efficiency for photovoltaic converters based on silicon single crystals due to the following operations:

\section{REFERENCES}

1. Z.A. Nikonova, O.Yu. Nebesnyuk, A.O. Nikonova, Kontaktni systemy $v$ elektronitsi (Zaporizhzhya: RVV ZDIA: 2015) [In Ukrainian].

2. Yimai Liang, Na Guo, Linlin Li, Ruiqing Li, Guijuan Ji, Shucai Gan, Appl. Surf. Sci. 332, 32 (2015).

3. Wenjun Wang, Hefeng Cheng, Baibiao Huang, Xiaolei Liu, Xiaoyan Qin, Xiaoyang Zhang, Ying Dai, J. Colloid Interface Sci. 442, 97 (2015).

4. Bilal Masood Pirzada, Niyaz A. Mir, Nida Qutub, Owais Mehraj, Suhail Sabir, M. Muneer, Mater. Sci. Eng. B 193, 137 (2015).

5. R. Loganathan, M. Jayasakthi, K. Prabakaran, R. Ramesh, P. Arivazhagan, K. Baskar, J. Alloy Compd. 616, 363 (2014).

6. Subhash Chand, Rajender Kumar, J. Alloy Compd. 613,
- $\quad$ structuring and reducing the thickness of the base crystals with the (111) orientation by deep chemical etching in an aqueous alkali solution;

- $\quad$ further formation of the epitaxial $n^{+}$-layer;

- formation of a double transparent luminous layer $\mathrm{In}_{2} \mathrm{O}_{3}+\mathrm{SnO}_{2}$.

The authors believe that the efficiency of solar cells can be increased by reducing the resistivity of $\operatorname{In}_{2} \mathrm{O}_{3} /$ $\mathrm{SnO}_{2}$ spheres and optimizing the contact illumination. Thus, the search for new constructive and technological solutions (introduction of extra spheres, formation of luminous coatings) of existing device structures and the formation of new materials will promote the development of photovoltaic devices and the transition to the mass industrial production of solar energy PECs.

\title{
Технологічні аспекти формування енергоефективних фотоелектричних перетворювачів сонячної енергї
}

\author{
О.Ю. Небеснюк, З.А. Ніконова, А.О. Ніконова
}

\begin{abstract}
Інженерний навчально-науковий інститут Запорізького національного університету, пр. Соборний, 226, 69006 Запоріжжя, Украӥна
\end{abstract}

\begin{abstract}
У наш час зростає попит на альтернативні джерела енергії, що використовуються в народному господарстві, промисловості та на побутовому рівні. Сонячна енергія е однією з найбільш перспективних альтернатив традиційним способам вироблення електроенергії. Актуальною проблемою е розробка економічних та відновлювальних технологій у виробництві фотоелектричних перетворювачів (ФЕП) на основі полі- та монокристалічного кремнію. Чітко проявляються тенденції створення найскладніших електронних пристроїв на основі багатошарових епітаксійних структур. При цьому формуються дуже високі вимоги до електрофізичних властивостей і досконалості структури кожного шару, ставляться завдання створення якісних та різких $p$ - $n$ переходів і гетеромеж на великих площах епітаксійних композицій. В статті запропоновано нові технологічні аспекти формування кремніевих наноструктур з прозорими просвітлюючими покриттями, які значно покращать якість ФЕП сонячної енергії на їх основі з ефективністю до 27 \%, що дасть поштовх для створення нових енергосистем.
\end{abstract}

Ключові слова: Сонячна енергія, Технологія, Будова, Фотоелектричні перетворювачі, Кремній, Наноструктури, Прозорі просвітлюючі шари, Параметри, Енергоефективність, Характеристики. 